\title{
The Regulation of Mutual Fund Debt
}

\author{
John Morley†
}

This Article offers the first general examination of mutual fund capital structure regulation under the Investment Company Act of 1940. The Article reaches two conclusions: First, the regulation of mutual funds' capital structure is incoherent. Although we might imagine several purposes for this regulation, such as limiting risks to investors and the financial system and preventing investor confusion, the regulation is not actually consistent with these purposes. It does both too much and too little to achieve them. Second, although at present the only type of security mutual funds can issue is common stock, there is no compelling reason why they should not also be allowed to issue debt securities. Debt securities might benefit investors by offering a safer and more stable alternative to the common stock of money market funds. Unlike shares in money market funds, debt securities could offer fixed interest rates and the safety of senior priorities. Such a proposal is clearly feasible, because mutual funds already borrow from banks and derivative counterparties, and they formerly issued debt securities in the era before regulation.

Introduction 344

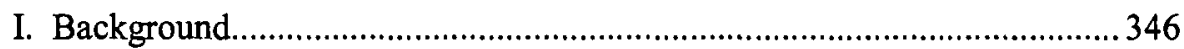

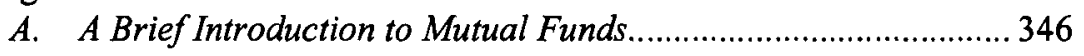

B. Capital Structure Regulation .................................................. 348

C. Current State of Mutual Fund Capital Structures....................... 352

D. The Practical Consequences of Capital Structure Regulation..... 353

1. Absence of Debt Securities ................................................... 353

2. Fragility of Money Market Funds ........................................353

II. The Early History of Mutual Fund Capital Structure Regulation...............356

A. Pre-1940 Debt Issuance........................................................ 356

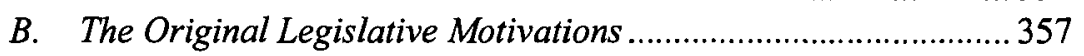

III. The Incoherence of Mutual Fund Capital Structure Regulation ............... 359

A. Systemic Risk .................................................................. 359

B. Investor Risk ................................................................ 360

C. Investor Confusion ............................................................. 361

$+\quad$ Associate Professor of Law, Yale Law School. Peter Conti-Brown, Quinn Curtis, Richard Hynes, Janna Manes, Roberta Romano, Aaron Schlaphoff, Andrew Verstein and workshop participants at the Colorado Junior Business Law Conference provided helpful comments. Jon Ashley of the University of Virginia Arthur J. Morris Law Library provided research assistance. 
D. Preventing Closed-End Funds from Trading at Premiums to NAV

IV. The Uneasy Case for Prohibiting Debt Securities .................................363

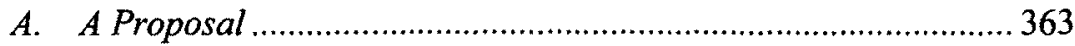

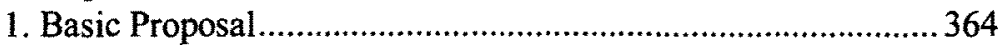

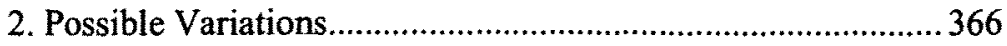

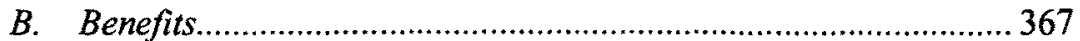

C. Arguments Against Allowing Debt Securities ............................. 369

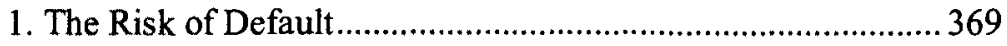

2. Systemic Risk..................................................................... 370

3. The Mechanical Challenges of Redemption Rights ............... 371

4. The Modigliani-Miller Theorem ........................................... 373

5. The Demand for Equity Interests ........................................ 374

6. Protecting Equity Investors from Risk ................................. 375

V. Conclusion

Introduction

In the United States, investors cannot buy bonds in a mutual fund. Indeed, investors cannot buy any sort of senior security in a mutual fund. Under the Investment Company Act of 1940, the only type of security mutual funds can issue is common stock, in a single layer of priority.

This simple restriction and other limits on mutual funds' capital structures have had profound effects on America's securities markets. With $\$ 12$ trillion in assets, the mutual fund industry is comparable in size to the commercial banking industry. ${ }^{1}$ Mutual funds own about a quarter of the outstanding stock of America's public companies and comprise about a quarter of American households' financial assets. ${ }^{2}$ The regulation of mutual fund capital structure is therefore responsible for the basic shape of one of America's most widely owned types of non-government securities. This regulation also accounts for hedge funds' ability to profit from leveraged investment strategies, the remarkable dearth of true interest-bearing instruments in most Americans' retirement portfolios, ${ }^{3}$ and the almost complete absence of bankruptcies among mutual funds in the last 70 years. Perhaps most crucially, this regulation is what made money market funds so oddly unstable during the recent financial crisis.

1. INV. CO. INST., 2012 INVESTMENT COMPANY FACT BOOK i (52d ed. 2012), http://www.ici.org/pdf/2012 factbook.pdf; see FED. RESERVE, INSURED U.S.-CHARTERED COMMERCIAL BANKS THAT HAVE CONSOLIDATED ASSETS OF $\$ 300$ MILlION OR MORE (2011), http://www.federalreserve,gov/releases/lbr/20111231//rg_bnk_lst.pdf.

2. INV. Co. INST., supra note 1 , at 10 fig.1.2, 12 fig.1.5.

3. Americans often buy common stock in funds that invest in debt instruments, but they cannot buy debt instruments from these funds. 
Despite its far-reaching impacts, however, the regulation of mutual funds' capital structure has attracted almost no attention from scholars or policymakers. Few academics in law or finance are even aware of the prohibition on debt issuance, for example, and no commentator since 1940 has ever attempted to explain its rationale. ${ }^{4}$ This is not because the regulation of mutual funds' capital structure is unimportant. To the contrary, it appears that this regulation is so deeply ingrained in the structure of American finance that almost everyone has simply taken it for granted.

The goal of this Article, therefore, is to begin a conversation. I wish to call attention to the regulation of mutual funds' capital structure and to suggest that regulators, economists and legal scholars should start seriously debating its merits. As anyone who reads a newspaper knows, bank capital structure is a matter of endless debate. Mutual fund capital structure now deserves our attention as well.

This Article begins the conversation by making two basic claims. First, the regulation of mutual funds' capital structure is incoherent. One might imagine several purposes for this regulation, including maintaining systemic stability, protecting equity investors from risk, and avoiding investor confusion. But even if one accepts the validity of these purposes, the regulation is not actually consistent with any of them. The regulation does both too much and too little to achieve the goals we might plausibly imagine for it. Further, the historical record reveals no clear purpose that might help us to rationalize this regulation. And it is not just the prohibition on debt issuance that is incoherent; other aspects of mutual fund capital structure regulation are incoherent as well.

Second, there is no compelling reason why mutual funds should not be allowed to issue debt securities to the public. Allowing mutual funds to issue debt might benefit the public by allowing investors to buy instruments that fit their preferences more closely than the instruments mutual funds are currently able to offer. At present, mutual funds cannot offer instruments with fixed interest rates or with fixed claims that are senior to more junior claims (such as common stock). Debt securities might fill these gaps. In so doing, debt securities might provide an appealing alternative to the common stock of

4. As a result of the collapse of several money market funds during the recent financial crisis, a few commentators have suggested that money market funds be allowed to issue floating-value common stock in addition to their fixed-value common stock. This Article contributes by considering capital structure regulation more broadly and by trying to uncover and explore its rationales. See Perspectives on Money Market Mutual Fund Reform: Hearing Before the S. Comm. on Banking, Housing, and Urban Affairs, 112th Cong. 2 (2012) (Statement of Jeffrey N. Gordon); PRESIDENT'S WORKING GROUP ON FIN. MKTS., MONEY MARKET FUND REFORM OPTIONS 32-35 (2010); WORKING GROUP ON FIN. REFORM, GROUP OF 30, FINANCIAL REFORM: A FRAMEWORK FOR FINANCIAL STABILITY 29 (2009) [hereinafter GROUP OF 30 REPORT]; Jeffrey N. Gordon, Why Investors Should Worry About Money Funds, WALL ST. J. (June 3, 2011), http://online.wsj.com/article/SB100014240527023 $04520804576343093940388186 \mathrm{html}$. The Squam Lake group has also proposed requiring fund advisors to supply capital cushions to money market funds. The Squam Lake Group, Reforming Money Market Funds (Tuck Sch. of Bus., Working Paper No. 2011-86), available at http://ssrn.com/abstract=1740663. 
money market funds. Unlike money market funds, debt securities could offer both fixed interest rates and the safety of senior priorities.

The prohibition on debt securities cannot be justified by the need to limit the amount and complexity of mutual funds' debt, because the prohibition on debt issuance concerns only the source of debt capital, not the amount or complexity. If the goal is to regulate the amount and complexity of mutual funds' debt, then we should simply regulate amount and complexity.

In fact, although few people seem to realize it, the perils of borrowingwhatever they may be-are already upon us. Mutual funds already borrow from banks and derivative counterparties, and they formerly issued debt securities to the public in the era before regulation. Mutual funds have handled the debt from these sources virtually without problem over the years, so it seems likely that broadening the sources of their borrowing could be both feasible and safe.

Part I of this Article begins with background on the structure of investment funds, the content of capital structure regulation, the consequences of this regulation, and the actual shape of mutual funds' capital structures. Part II explores the historical origins of capital structure regulation. Part III then makes the claim that this regulation is incoherent, and Part IV argues that there is no compelling reason to prohibit mutual funds from issuing debt securities to the public.

\section{Background}

\section{A. A Brief Introduction to Mutual Funds}

Mutual funds are commonly defined as pools of stocks, bonds, and other investment securities. Mutual funds sell shares in these pools to members of the general public, who can buy the shares to invest for retirement or other purposes. Because mutual funds sell their shares widely to the general public, they must comply with the Investment Company Act of 1940 (ICA) and register with the SEC. ${ }^{5}$ Mutual funds are operated by separately owned and separately incorporated companies commonly known as "advisers" or "managers." These advisers often operate dozens of mutual funds and they exercise great control over mutual funds' investment choices and other activities. Advisers include companies like Fidelity, Goldman Sachs and Vanguard.

One of mutual funds' key features is that they allow their shareholders to "redeem" their shares. In other words, shareholders can turn over their shares to

5. The registration requirement appears in Investment Company Act $\S 3,15$ U.S.C. $\S 80 a-3$ (2006). Exemptions for funds that offer securities only to limited numbers of investors appear in 15 U.S.C. $\$ 80 \mathrm{a}-3(\mathrm{c})(1),(7)$.

6. John Morley, The Separation of Investments and Management, 123 YALE L.J. (forthcoming 2013), available at http://papers.ssrn.com/sol3/papers.cfm?abstract id=2240468. 
the funds and receive cash in exchange. The cash amount is equal to the value of the portion of a fund's net assets (i.e., its assets minus its liabilities) that corresponds to each share. This amount is known as a fund's "net asset value," or "NAV." Mutual funds typically allow their shareholders to redeem every day.

Mutual funds are sometimes called "open-end" funds to distinguish them from "closed-end funds." Closed-end funds are similar to mutual funds in many respects. They are pools of investment securities, they sell interests widely to the general public, and they must comply with the ICA. The primary difference between open- and closed-end funds is that closed-end funds do not allow shareholders to redeem. Closed-end funds' shares are bought and sold on exchanges much like the shares of operating companies. And like operating companies, closed-end funds exist perpetually.

"Exchange-traded" funds (ETFs) are a special kind of open-end mutual fund. The primary difference between exchange-traded funds and other mutual funds is that exchange-traded funds' shares can only be redeemed in large blocks and only in kind. ${ }^{7}$ As a consequence, retail investors tend to acquire and dispose of ETF shares by buying and selling them on exchanges, rather than by buying and redeeming them in direct transactions with the funds.

Money market funds are another special kind of open-end mutual fund. Money market funds are so named because they can invest only in short-term debt securities of low-risk issuers-i.e., in the "money market." Regulation requires any fund that uses the name "money market fund" to adhere to strict regulations limiting the riskiness and duration of its portfolio. Additionally, money market funds attempt to maintain a constant net asset value of $\$ 1$ per share even if their actual net asset values fall slightly above or below $\$ 1$ per share. In other mutual funds, the net asset value varies mechanically with the value of the assets. Money market funds accomplish this by using an accounting method that values portfolio assets at historical cost, rather than fair value. ${ }^{9}$

Mutual funds are similar in many respects to hedge funds. Like mutual funds, hedge funds invest in securities and other assets and offer their shareholders redemption rights. Unlike mutual funds, however, hedge funds are exempt from the ICA, because they accept investments only from wealthy

7. Exchange-traded funds' shares may also be bought and sold on exchanges (hence the name, "exchange-traded fund"). However, funds always stand willing to buy and sell shares in direct transactions. This places both a floor and a ceiling on exchange prices and keeps exchange prices roughly in line with the funds' net asset values. See generally William A. Birdthistle, The Fortunes \& Foibles of Exchange-Traded Funds: A Positive Market Response to the Problems of Mutual Funds, 33 DEL. J. CORP. L. 69 (2008).

8. The money market fund regulations are contained in ICA Rule 2a-7. 17 C.F.R. $\$ 270.2 a-7$ (2012).

9. See infra note 31 and accompanying text. 
individuals and institutions. ${ }^{10}$ Hedge funds typically allow shareholders to redeem only once per month or once per quarter.

Ordinary open-end mutual funds are by far the largest of these various categories of funds. Ordinary mutual funds (by which I mean open-end mutual funds other than money market and exchange-traded funds) collectively hold about $\$ 9$ trillion in assets. ${ }^{11}$ Money market funds hold an additional $\$ 2.7$ trillion, while ETFs hold $\$ 1$ trillion and hedge funds hold $\$ 1.7$ trillion. ${ }^{12}$

\section{B. Capital Structure Regulation}

The ICA regulates the capital structure of both open-end mutual funds and closed-end investment funds. For analytical purposes, I divide the ICA's capital structure regulation into three dimensions: (1) the sources of debt capital; (2) the form of debt capital; and (3) the amount of debt capital. Dividing the regulation in this way is useful because it helps to illustrate that these dimensions are independent and they each serve different purposes.

First, the ICA regulates the sources of debt capital. It does so mainly by prohibiting open-end mutual funds from taking on debt obligations to anyone other than banks. ${ }^{13}$ That is, if a mutual fund wishes to borrow, it must do so from a bank, and not from the general public, a brokerage house, or any other kind of lender. The ICA places this restriction by requiring that open-end funds not issue "senior securities" to anyone other than a bank and by defining "senior securities" very broadly to include any "evidence of indebtedness."

Second, the ICA regulates the form of funds' obligations and securities. The only kind of security the ICA permits open-end funds to issue to people other than banks is a single layer of common stock. Mutual funds cannot issue any form of preferred stock or bond. Mutual funds can issue multiple classes of common stock, but these classes can vary only with respect to fees, and not with respect to voting rights, dividend preferences or liquidation priorities. ${ }^{15}$ The ICA places no restrictions on the form of borrowing relationships between open-end funds and banks.

The form restrictions are slightly more permissive with respect to closedend funds. In addition to issuing a single class of common stock, closed-end funds can also issue a single class of debt security and a single class of preferred stock. $^{16}$

10. 15 U.S.C. $\$ 80 \mathrm{a}-3(\mathrm{c})(1),(7)(2006)$.

11. INV. CO. INST., supra note 1 , at $136 \mathrm{tbl} .3$.

12. Id. at 136 tbl.3, 146 tbl.13; Hedge Fund Industry-Assets Under Management, BARCLAYHEDGE, http://www.barclayhedge.com/research/indices/ghs/mum/HF_Money_Under_ Management.html (last visited Mar. 24, 2013).

13. 15 U.S.C. $\S 80 \mathrm{a}-18(f)(1)(2006)$.

14. Id. $\S 80 \mathrm{a}-2(\mathrm{a})(36)$.

15. Id. $\S 80 \mathrm{a}-18(\mathrm{ff}(3) ; 17$ C.F.R. $\S 270.18 \mathrm{f}-3$ (2012).

16. Id. $\$ 80 \mathrm{a}-18(\mathrm{a})$. 
Finally, the ICA regulates the amount of debt capital. In an open-end mutual fund, the ratio of total net assets to bank-loan principal must always equal or exceed $3 / 1 .{ }^{17}$ For purposes of calculating this ratio, "total net assets" means total assets minus all liabilities not represented by senior securities, which include bank loans. Mutual funds must maintain this coverage ratio continuously. If the value of their assets declines, they must reduce their debt within three days (not including Sundays and holidays) to maintain the appropriate ratio. ${ }^{18}$

The restrictions are more permissive with respect to closed-end funds. As in open-end funds, in closed-end funds the ratio of total assets to debtincluding both bank loans and debt securities-must equal or exceed 3/1. ${ }^{19}$ Unlike open-end funds, however, closed-end funds are also permitted to issue preferred stock in addition to bonds and common stock. For preferred stock, the required ratio of total assets to liabilities is only $2 / 1 .{ }^{20}$ For purposes of

17. Section $18(\mathrm{f})(1)$ of the ICA states that an open-end fund must maintain at least $300 \%$ asset coverage for bank borrowings. 15 U.S.C. $\S 80 \mathrm{a}-18(\mathrm{f})(1)$ (2006). Section $18(\mathrm{~h})$ defines "asset coverage" as follows:

"Asset coverage" of a class of senior security representing an indebtedness of an issuer means the ratio which the value of the total assets of such issuer, less all liabilities and indebtedness not represented by senior securities, bears to the aggregate amount of senior securities representing indebtedness of such issuer.

15 U.S.C. $\$ 80 \mathrm{a}-18(\mathrm{~h})(2006)$. Note that the term "senior security representing an indebtedness of an issuer" apparently includes loans from banks. This is implicit in section $18(f)$ of the ICA, which speaks of "asset coverage" for bank borrowings, and section $18(\mathrm{~g})$, which carves out bank borrowings from the definition of "senior security" but only for a narrow set of purposes not relevant here, suggesting that the term "senior security" includes bank borrowings for all other purposes under section 18 .

The asset coverage requirement might be expressed mathematically in the following ratio:

$$
(A-L+B) / B
$$

where $A$ is total assets, $L$ is total liabilities (including bank borrowing), and $B$ is the liabilities attributable to bank borrowing. One could thus say the ICA requires a debt-to-equity ratio of less than $1 / 2$. This is evident if we simplify the ratio above as follows:

$$
((A-L) / B)+1
$$

where (A-L) can be thought of as the fund's total net assets or equity. By subtracting off the " 1 ," we see that the necessary equity-to-debt ratio is at least $2 / 1$.

18. 15 U.S.C. $\$ 80 \mathrm{a}-18(\mathrm{f})(1)(2006)$.

19. Id. $\S 80 \mathrm{a}-18(\mathrm{a})(1)(\mathrm{A})$.

20. To put it more precisely, preferred stock must have $200 \%$ "asset coverage" immediately after the sale of the stock. Id. $\S 80 \mathrm{a}-18(\mathrm{a})(2)(\mathrm{A})$. For preferred stock, the ICA defines "asset coverage" to mean

the ratio which the value of the total assets of such issuer, less all liabilities and indebtedness not represented by senior securities, bears to the aggregate amount of senior securities representing indebtedness of such issuer plus the aggregate of the involuntary liquidation preference of such class of senior security which is a stock. The involuntary liquidation preference of a class of senior security which is a stock shall be deemed to mean the amount to which such class of senior security would be entitled on involuntary liquidation of the issuer in preference to a security junior to it.

15 U.S.C. $\$ 80 \mathrm{a}-18(\mathrm{~h})(2006)$.

Mathematically, the ratio can be expressed as follows:

$$
(A-L+D+B+P) /(D+B+P)
$$

where $A$ is total assets, $\mathrm{L}$ is total liabilities, $\mathrm{D}$ is the aggregate liabilities attributable to debt securities, $B$ is the aggregate liabilities attributable to bank borrowing, and $\mathrm{P}$ is the aggregate amount of liquidation preference for the preferred stock. Since D, B and P are all included in the definition of senior securities 
calculating this $2 / 1$ ratio, preferred stock, bank loans and debt securities are cumulated. The net result of these restrictions is that closed-end funds can have a maximum total debt-to-assets ratio (including all types of debt associated with bank borrowing, senior securities and preferred stock) of $1 / 2$.

Unlike open-end funds, closed-end funds are not generally required to maintain their asset-to-debt ratios continuously, so long as they have the appropriate ratios at the time the borrowings are first made. ${ }^{21}$ However, if closed-end funds fall sufficiently far below their basic asset-to-debt ratios or fail to make dividend payments on preferred stock for sufficiently long periods of time, then the ICA prevents these funds from paying dividends to common stock holders and requires the funds to give debt holders or preferred stockholders voting control over the funds. ${ }^{22}$

in section $18(\mathrm{~g})$, this expression adds them back to the denominator to ensure that only liabilities not represented by senior securities are excluded, as instructed by section $18(a)(2)(A)$. Rearranging, we can simplify the expression above as follows:

$$
(A-L) /(D+B+P)+I \text {. }
$$

Again subtracting off the " 1 ," we see that closed-end funds may not exceed a total debt-to-equity ratio of $1 / 1$.

21. Id. $\S 80 \mathrm{a}-18(\mathrm{a})(1)(\mathrm{A}),(2)(\mathrm{A})$ (assessing capital ratio compliance for the issuance of both debt and preferred stock "immediately after ... issuance or sale," rather than on an ongoing basis.).

22. For debt securities, the ICA states in section $18(\mathrm{a})(1)(\mathrm{B})-(\mathrm{C})$ :

(B) provision [must be] made to prohibit the declaration of any dividend (except a dividend payable in stock of the issuer), or the declaration of any other distribution, upon any class of the capital stock of such investment company, or the purchase of any such capital stock, unless, in every such case, such class of senior securities has at the time of the declaration of any such dividend or distribution or at the time of any such purchase an asset coverage of at least 300 per centum after deducting the amount of such dividend, distribution, or purchase price, as the case may be, except that dividends may be declared upon any preferred stock if such senior security representing indebtedness has an asset coverage of at least 200 per centum at the time of declaration thereof after deducting the amount of such dividend; and

(C) provision [must be] made either-

(i) that, if on the last business day of each of twelve consecutive calendar months such class of senior securities shall have an asset coverage of less than 100 per centum, the holders of such securities voting as a class shall be entitled to elect at least a majority of the members of the board of directors of such registered company, such voting right to continue until such class of senior security shall have an asset coverage of 110 per centum or more on the last business day of each of three consecutive calendar months, or

(ii) that, if on the last business day of each of twenty-four consecutive calendar months such class of senior securities shall have an asset coverage of less than 100 per centum, an event of default shall be deemed to have occurred....

Id. $\S 80 \mathrm{a}-18(\mathrm{a})(1)(\mathrm{B})-(\mathrm{C})$.

For preferred stock, the ICA states in section $18(a)(2)(B)-(C)$ :

(B) provision [must be] made to prohibit the declaration of any dividend (except a dividend payable in common stock of the issuer), or the declaration of any other distribution, upon the common stock of such investment company, or the purchase of any such common stock, unless in every such case such class of senior security has at the time of the declaration of any such dividend or distribution or at the time of any such purchase an asset coverage of at least 200 per centum after deducting the amount of such dividend, distribution or purchase price, as the case may be;

(C) provision [must be] made to entitle the holders of such senior securities, voting as a class, to elect at least two directors at all times, and, subject to the prior rights, if any, of the holders of any other class of senior securities outstanding, to elect a majority of the directors if at any time dividends on such class of securities shall be unpaid in an amount equal to two full years' 
Both open- and closed-end funds may borrow for short-term purposes in amounts up to $5 \%$ of the funds' total assets without regard to the amount restrictions just described. ${ }^{23}$

The primary complication to this simple summary is that, because the ICA prohibits open-end mutual funds from issuing "senior securities" to anyone other than a bank, the SEC has been forced to define what a "senior security" is in very precise ways. The ICA defines senior securities broadly to include any "evidence of indebtedness," and so the SEC has had to think through difficult questions such as whether short sales, sales of call and put options, sales of forward contracts and sales of other derivative obligations that require future performance constitute "senior securities." These transactions all resemble borrowing, because they allow a fund to receive something immediately in return for a promise to pay something in the future. When a fund enters a short sale, for example, it receives payment for the security immediately, but does not actually have to deliver the security until some settlement date in the future. As derivative instruments have become increasingly complicated, so too have the questions about whether particular types of derivatives are senior securities.

The SEC has dealt with this problem by adopting what essentially amounts to a two-step strategy. First, the SEC has defined "senior securities" very broadly. And second, the SEC has allowed funds to buy and sell many derivative instruments that clearly qualify as "senior securities" so long as the funds comply with various regulations. The regulations consist mostly of a set of rules requiring funds to segregate assets to cover the full notional value of all liabilities associated with derivatives. ${ }^{24}$ The segregated assets may not be used to pay for redemptions by equity holders or to secure other obligations. Returns on the segregated assets may be taken by the funds, however, and the funds can

dividends on such securities, and to continue to be so represented until all dividends in arrears shall have been paid or otherwise provided for. ...

Id. $\S 80 \mathrm{a}-18(\mathrm{a})(2)(\mathrm{B})-(\mathrm{C})$.

23. Id. $\S 80 \mathrm{a}-18(\mathrm{~g})$.

24. Securities Trading Practices of Registered Investment Companies, Investment Company Act Release No. IC-10666, 44 Fed. Reg. 25,128 (Apr. 27, 1979) (codified at 17 C.F.R. pt. 271), One way to cover is to set aside a pool of liquid assets (such as exchange-traded securities, cash, or government securities) that are marked to market daily. A fund can do this through a combination of margin postings and transactions on its own books. Funds must add or remove assets on a daily basis to ensure that the accounts always.have enough assets to cover the full notional amounts of the liabilities being covered. Funds may not discount the liabilities for the probability of their realization or for the time-value of money. For example, if a fund sells a call option exercisable one year from now at $\$ 10$, and the stock is currently trading at $\$ 12$, the fund must set aside exactly $\$ 2$ today, whether or not the value of the stock or the segregated assets is expected to change between now and the exercise date.

Certain types of transactions can also be covered by entering into offsetting transactions. For example, a short sale or a sold call option can be covered by holding the underlying security. Additionally, a fund that has sold a put option can cover by selling short the underlying security at the same or a higher price than the strike price of the put option. Transactions covered by entering into offsetting transactions do not have to be covered by a segregated pool of assets.

The management and details of these segregated pools and offsetting transactions have been the subject of many SEC No-Action Letters. See, e.g., Dreyfus Strategic Investing and Dreyfus Strategic Income, SEC No-Action Letter, [1987 Transfer Binder] Fed. Sec. L. Rep. (CCH) \ 48,525 (June 22, 1987). 
freely remove and substitute assets in the segregated accounts, meaning that in most economic respects the segregated accounts are parts of funds' portfolios.

The net result of the derivative asset segregation system is that funds can achieve substantial leverage through the use of derivatives. ${ }^{25}$ The asset segregation system is vaguely similar to a requirement that derivative obligations be secured, when the security can consist partly of the proceeds received from the borrowing itself. Thus, in a sense, as long as funds have adequate security, they can freely borrow through derivatives.

All of the sparse academic and practitioner commentary on the regulation of mutual fund capital structure has focused on this complicated problem of defining a "senior security" and on the asset coverage system it has necessitated. ${ }^{26}$ I will not directly address this problem, however. I will focus instead on what I consider the larger and more interesting problem that academic researchers and practitioners have mostly ignored: why the ICA prohibits mutual funds from issuing senior securities in the first place.

\section{Current State of Mutual Fund Capital Structures}

At present, there is no solid data on the state of mutual funds' capital structure. This is consistent with the almost total disregard academics have shown to the topic. My impression, however, is that bank borrowing is not terribly common but does occasionally occur. In particular, mutual funds tend to borrow from banks for short-term purposes, such as raising cash to meet redemption demands. Some funds also borrow purely for leverage purposes, although these funds appear to be relatively rare. Some funds achieve leverage indirectly. Recent years have seen rapid growth in "130/30" funds, which essentially leverage by making short sales on margin. Some exchange-traded funds and ordinary mutual funds also achieve leverage by entering into daily settled swap agreements with external counterparties. Under these agreements, the funds pay or receive some multiple (e.g., two times or three times) of losses or gains on some index, like the S\&P 500 .

25. To see how a fund might achieve leverage through derivatives in spite of the asset segregation system, imagine a forward contract in which a fund receives $\$ 10$ at time 0 in exchange for a promise to deliver an asset at time 1 whose value is presently $\$ 11$. If we ignore the potential variance in the value of the deliverable asset between times 0 and 1 , then this contract looks very much like a loan, in which the borrower receives $\$ 10$ at time 0 in return for an obligation to repay $\$ 10$ plus $10 \%$ interest at time 1 . Since the fund only has to segregate $\$ 11$ in connection with this loan, the fund can, in effect, procure a $\$ 10$ loan with only $\$ 1$ in equity, achieving an asset coverage ratio of only $11 / 10$. In this example, the only real constraint imposed by the asset segregation system is that the fund may not use the segregated assets to meet redemptions or operating expenses or to cover further derivative obligations or secure further loans. Thus, the fund in this example must keep a few dollars of equity to pay operating expenses and redemptions, in addition to maintaining the $\$ 1$ of equity in the segregated account.

26. See, e.g., Jay G. Baris, ET AL., COMM. ON FED. Regulation of SEC., ABA SEction on BUS. LAW, AM. BAR ASS'N, REPORT OF THE TASK FORCE ON INVESTMENT COMPANY USE OF DERIVATIVES AND LEVERAGE (2010). 
In contrast to open-end funds, closed-end funds are allowed to issue senior securities, and they do so with some frequency. They tend to issue "Auction Market Preferred Securities," or AMPS. ${ }^{27}$ For regulatory purposes, AMPS are characterized as preferred stock, but for practical purposes they function like bonds. In essence, AMPS are bonds that are rolled over periodically. The funds hold auctions for securities that pay a particular interest rate, and whichever investor bids the highest price for the securities is allowed to purchase them.

\section{The Practical Consequences of Capital Structure Regulation}

Although they have been ignored by academic researchers, the regulations on mutual funds' capital structure have had tremendous practical consequences. Let us identify just three of the most important here.

\section{Absence of Debt Securities}

Most obviously, mutual funds cannot issue debt securities that have either (a) fixed interest rates or (b) fixed claims with senior priorities. Mutual funds comprise almost a quarter of household financial assets in the United States, ${ }^{28}$ so this regulation has had profound consequences for the retirement portfolios of household investors, as well as for the cash management of businesses and institutions. And although many Americans invest in the common stock of funds that invest in debt, ${ }^{29}$ they receive no guarantees about returns or interest from these funds and no insulation from junior claimants against the losses of their principal. Institutional investors are similarly unable to obtain interestbearing senior instruments, even though, as I explain below, their demand for such instruments may be great.

\section{Fragility of Money Market Funds}

As a result of the financial crisis and the resulting collapses of a handful of money market funds, academics and popular commentators have recently focused enormous attention on the instability inherent in the structure of these funds. ${ }^{30}$ What few seem to realize, however, is that this instability is an

27. INV. Co. INST., supra note 1, at 61-63.

28. See id. at 10 fig.1.2.

29. Id. at 32-33 (describing recent inflows to bond and hybrid mutual funds).

30. See, e.g., Hilary J. Allen, Money Market Fund Reform Viewed Through a Systemic Risk Lens, 11 J. BuS. \& SEC. L. 87 (2010); William A. Birdthistle, Breaking Bucks in Money Market Funds, 2010 WIS. L. REV. 1155 (2010); Burcu Duygan-Bump, et al., How Effective Were the Federal Reserve Emergency Liquidity Facilities? Evidence from the Asset-Backed Commercial Paper Money Market Mutual Fund Liquidity Facility, 68 J. FIN. 715 (2013); Gary Gorton \& Andrew Metrick, Regulating the Shadow Banking System, 1970 BROOKINGS PAPERS ON ECON. ACTIVITY 261 (2010); Sergey Chernenko \& Adi Sunderam, The Quiet Run of 2011: Money Market Funds and the European Debt Crisis (Fisher Coll. of Bus. Working Paper 2012-4, 2012), available at http://www.ssrn.com/abstract =1991171; Jeffrey N. Gordon, Letter to the SEC on Money Market Fund Reform (Columbia Law and Econ. 
inadvertent product of the ICA's capital structure regulations. The prohibition on debt issuance has perversely forced money market funds into a capital structure that consists entirely of debt.

Money market funds' instability results from their pledge to maintain a $\$ 1$ net asset value. Recall that the net asset value is the proportion of the fund's assets, net of liabilities, that corresponds to each share. Money market funds maintain the stability of their net asset values by using a method of valuation known as "amortized cost." Using this method, funds can value their securities at cost plus implicit interest, rather than at fair market value. If the amortized cost and fair market value methods diverge too widely, money market funds must depart from the $\$ 1$ share value and reprice their shares at fair market NAV. ${ }^{31}$

These constant net asset values make money market funds unstable because there can be a gap between the time a fund's fair-value NAV drops below $\$ 1$ and the time a fund ceases to offer shareholders redemption at $\$ 1$. This can set the stage for a classic run on the bank: shareholders who redeem early get $\$ 1$, and shareholders who redeem late get less than $\$ 1$-and even less than their proportional entitlements, since the early redeemers take more than their fair shares by taking more than NAV. During the financial crisis, this dynamic famously caused the collapse of the Reserve Primary Fund, a major money market fund whose net asset value dropped below $\$ 1$ after its heavy investment in the debt of Lehman Brothers declined in value with Lehman's bankruptcy. Other funds also experienced runs during the crisis. ${ }^{32}$

When the industry first asked the SEC for the rule changes that enabled constant net asset value pricing in the 1970s, the industry was trying to craft a product that could appeal to investors as a substitute for bank deposits. ${ }^{33}$

Working Paper No. 352, Sept. 9, 2009), available at http://ssrn.com/abstract=1473275; Marcin Kaperczyk \& Philipp Schnabl, How Safe Are Money Market Funds? (AFA Chi. Meetings Paper, 2012), available at http://ssrn.com/abstract $=1769025$; Jonathan R. Macey, Reducing Systemic Risk: The Role of Money Market Mutual Funds as Substitutes for Federally Insured Bank Deposits (Yale Law and Econ. Research Paper No. 422, 2011), available at http://ssrn.com/abstract=1735008; Patrick E. McCabe, The Cross-Section of Money Market Fund Risks and Financial Crises (Fed. Res. Sys. Working Paper No. 2010-51, 2010), available at http://ssrn.com/abstract=1898341; The Squam Lake Group, Reforming Money Market Funds (Tuck Sch. of Bus. Working Paper No. 2011-86), available at http://ssrn.com/abstract=1740663; Mercer E. Bullard, Federally Insured Money Market Funds and Narrow Banks: The Path of Least Insurance (Mar. 2, 2009) (unpublished manuscript), available at http://ssm.com/abstract=1351987; Melanie L. Fein, The Perceived Guarantee of Bank-Affiliated Money Market Funds (Oct. 6, 2010) (unpublished manuscript), available at http://ssrn.com/abstract=1688434; Russ Wermers, Runs on Money Market Mutual Funds (Mar. 15, 2012) (unpublished manuscript), available at $\mathrm{http}: / / \mathrm{ssrn}$. com/abstract $=2024282$.

31. PRESIDENT'S WORKING GROUP ON FIN. MKTS., supra note 4, at 7 .

32. Investors in the Reserve Primary Fund who failed to get out before redemptions were suspended received slightly over 99 cents per share. Jill Fisch \& Eric Roiter, A Floating NAV for Money Market Funds: Fix or Fantasy?, 2012 U. ILL. L. REV. 1003, 1032; Letter from John D. Hawke, Jr., Arnold \& Porter, to Elizabeth M. Murphy, Secretary, SEC, re: File No. 4-619, at 3 (Feb. 24, 2011), available at www.sec.gov/comments/4-619/4619-82.pdf.

33. Matthew Fink, who was head of the Investment Company Institute at the time the money market fund rules were adopted, argues that the mutual fund industry in the 1970s saw money market 
Investors prefer investments with definitely fixed values for a number of reasons. Institutional investors, such as insurance companies, municipalities, government agencies and corporations, are often allowed to invest in money market funds in part because of their fixed values. Additionally, fixed values make it easy for institutional investors to move their money around with a minimum of accounting and recordkeeping, because fixed value shares eliminate realizations of capital gains and losses at the time of redemptions. ${ }^{34}$ Retail investors also prize fixed value investments, because fixed values allow these investors to treat money market funds like bank accounts.

Fixed-NAV common stock came about as an attempt to meet this demand without running afoul of the statutory prohibition on debt. Even though fixedNAV common stock looks like debt for many practical purposes, the SEC has been willing to treat it like common stock for purposes of the ICA, because it lacks two key features of debt. First, it does not pay interest. Common stock in money market funds pays only dividends, and the dividends are not fixed or predictable like interest payments. Second, common stock in money market funds does not offer a senior claim, because even though it offers a kind of fixed value, it is not protected from losses by any sort of junior claim. There is no floating value stock to bear losses before the fixed-value stock.

This is how the prohibition on debt issuance pushed money market funds into a capital structure that consists entirely of debt. In order to avoid running afoul of the prohibition on "senior" securities, money market funds simply do not issue "junior" securities. Since these funds cannot have two classes of securities, they have only a single class of security that looks a lot like debt.

The reason money market funds have managed to survive so long in spite of having no real equity is two-fold. First, money market funds' portfolios are much more conservative and much shorter-term than those of banks and ordinary mutual funds. By law, money market funds can invest only in instruments that mature within a few days and are issued by highly creditworthy companies. ${ }^{35}$ Banks, by contrast, can hold loans that last thirty years or more and can extend these loans to individual consumers and businesses with imperfect credit histories. Second, money market funds do not pay fixed interest rates. This gives them some flexibility in deciding how much of their income to distribute.

funds as a way to compete with savings accounts, which at the time were prohibited by treasury regulations from paying interest rates high enough to keep pace with inflation. MATTHEW FINK, THE RISE OF MUTUAL FUNDS: AN INSIDER'S VIEW 80 (2d ed. 2008).

34. See, e.g., Fisch \& Roiter, supra note 32, at 1015-16.

35. Rule $2 \mathrm{a}-7$ requires, among other things, that money market funds "not . . . [m]aintain a dollar-weighted portfolio maturity that exceeds 60 calendar days," 17 C.F.R. $\$ 270.2 a-7$ (c)(2)(ii) (2012), and that they "limit ... portfolio investments to those United States Dollar-Denominated securities that the fund's board of directors determines present minimal credit risks." Id. § 270.2a-7(c)(3)(i). 


\section{The Early History of Mutual Fund Capital Structure Regulation}

A brief review ${ }^{36}$ of the mutual fund industry's early history suggests two insights about mutual fund capital structure: first, mutual funds successfully issued bonds and preferred stock in the era before regulation, and second, the historical record reveals no central rationale for the capital structure regulations. The legislative history suggests a mishmash of possible rationales, none of which were very clearly articulated by the ICA's advocates.

\section{A. Pre-1940 Debt Issuance}

Of the approximately eighty open-end funds in existence in 1940, at least five, including two with assets in excess of $\$ 20$ million, issued senior securities. $^{37}$ The phenomenon apparently grew in popularity between the mid1930s and 1940, and it might have continued to grow in popularity had the ICA not prohibited it. ${ }^{38}$

Some of the details are evident in prospectuses for debt securities issued by three early funds: Republic Investors Fund, Inc., Affiliated Fund, Inc., and Managed Estates, Inc. ${ }^{39}$ These funds allowed equity redemptions at frequencies ranging from one to seven days. The funds issued bonds with annual interest rates in the neighborhood of 5\% and maturities of ten years. The bonds were redeemable on thirty days' notice at discounts to par that decreased with time. Interest accrued daily, but was paid out to debt holders two to four times per year. Managers charged fees by taking underwriting commissions.

Each of these funds secured its bonds by depositing assets with trustees. One fund also gave debt holders a lien on all of the fund's assets; the other two simply prohibited trustees from paying out any of the deposited assets to redeeming equity holders if the assets' value fell below a multiple of the bonds' outstanding principal. The multiples were $120 \%$ and $150 \%$. The bond indentures allowed new securities to be issued only if the funds satisfied certain capital ratios at the time of issuance. The maximum ratios of total assets to debt ranged from $5 / 3$ to $3 / 2$. These ratios are much lower, and therefore less conservative, than the $3 / 1$ ratio that the ICA now requires for bank borrowings. These historical funds invested broadly in exchange-listed common stocks and other exchange-listed securities. One of the funds also issued preferred stock in addition to bonds.

36. For a more general discussion of the ICA's legislative history, see John Morley, Collective Branding and the Origins of Investment Fund Regulation, 6 VA. L. \& BUS. REV. 341 (2012).

37. A Bill to Provide for the Registration of Investment Companies and Investment Advisers, and for Other Purposes: Hearing Before a Subcomm. of the Comm. on Banking and Currency, 76th Cong. 461 (1940) [hereinafter Registration Bill Hearing].

38. Morley, supra note 36, at 387.

39. COMSEC CORP., PROSPECTUS (1935) (on file with author); MANAGED ESTATES, INC., PRospectus (1936) (on file with author); REPUBLIC INVESTORS FUND, INC., PROSPECTUS (1936) (on file with author). 
Although only a minority of mutual funds issued debt securities prior to 1940 and although most of the debate about the regulation of open-end funds' capital structures occurred behind closed doors and produced no traces in the historical record, it is clear that important players defended the open-end mutual fund industry's right to issue debt securities during the fight over the ICA. The most important was Merrill Griswold. His fund, Massachusetts Investors Trust, was by far the largest single open-end fund in 1940. It held about $22 \%$ of the industry's total assets. ${ }^{40}$ Griswold wrote a letter to the SEC arguing that he saw "no fundamental objection to the inclusion of bonds or preferred stock in capital structures." 41 The letter proposed that instead of prohibiting senior securities, the ICA should adopt "proper safeguards . . . to assure the fact that any such senior securities will be well protected by asset value of the companies in question. ..."42 Hugh Bullock, who ran another large open-end fund management company, also opposed the prohibition on debt issuance. $^{43}$

\section{B. The Original Legislative Motivations}

The legislative history does not reveal any central rationale for the capital structure regulations. It reveals instead an array of possible explanations and rationales. None of these was very clearly articulated by the SEC, which drafted and championed the ICA, but they are nevertheless worth exploring.

The first possible explanation is that the SEC wanted to address problems unique to closed-end funds, rather than open-end funds. When the SEC drafted the ICA in 1940, its attention focused overwhelmingly on closed-end funds. Up until the very end of the $1930 \mathrm{~s}$, closed-end funds held far more assets than open-end funds did. ${ }^{44}$ Additionally, closed-end funds had piled up a far uglier track record of scandals in the 1920 s and 1930s than open-end funds had. ${ }^{45}$ The SEC was especially concerned about closed-end funds' capital structures, because borrowing contributed to these funds' tendency to trade at premiums

40. See Registration Bill Hearing, supra note 37, at 459-61 (divide total assets for Massachusetts Investors Trust by the total assets for all open -end funds); Natalie R. Grow, The "BostonType Open-End Fund"-Development of a National Financial Institution: 1924-1940, at 342 tbl.22 (Apr. 30, 1977) (unpublished $\mathrm{Ph} . \mathrm{D}$. dissertation, Harvard University) (on file with the Harvard University Archives, Harvard University) (showing the growth of Massachusetts Investors Trust in comparison to other large open-end funds in the late 1930s).

41. Letter from Merrill Griswold, Chairman, Mass. Inv. Trust and Hugh Bullock, VicePresident, Calvin Bullock, Inc. (on file with author).

42. Id.

43. Id.

44. Morley, supra note 36 , at 350 fig.2.

45. Beginning in 1936, the SEC held administrative hearings and compiled a report of several thousand pages describing the investment fund industry. Parts 1 and 2 described the basic origins and characteristics of both types of funds. Part 3 devoted several thousand pages to scandals in closed-end funds. There was no comparable report on scandals in open-end funds. See generally SEC. \& EXCH. COMM'N, INVESTMENT TRUSTS AND INVESTMENT COMPANIES, H.R. DOC. No. 75-707, pt. 3 (19381942). 
over their net asset values. ${ }^{46}$ In other words, the common stock of funds with borrowed money tended to trade at prices that were higher than the funds' net asset values. No one knows for sure why this was the case- - or why funds ever traded at premiums to NAV at all-but this tendency became exacerbated as funds borrowed more money. The SEC found premium-trading troubling because it allowed closed-end funds' managers and underwriters to prey on investors' lack of sophistication: managers and underwriters could buy the securities of operating companies at one price and then turn around and sell them at a higher price simply by dumping them into a closed-end fund. Closedend funds ceased to trade at premiums to net asset value after the great crash of 1929, but premium-trading nevertheless continued to concern the SEC in 1940.

Borrowing was also problematic in closed-end funds because it accelerated these funds' collapses in the great crash of 1929. Closed-end funds had all invested heavily in common stocks, and so when the value of these stocks crashed in 1929, leverage greatly accelerated the losses.

Perhaps the reason open-end funds ended up with tighter restrictions on senior securities than closed-end funds is simply that in 1940 most open-end funds still issued only common stock. ${ }^{47}$ Further, the ICA grandfathered the debt issues of funds that had already issued debt, perhaps eliminating much of the potential opposition to the debt prohibition. ${ }^{48}$

A second possible historical rationale involves what I have elsewhere called "collective branding." 49 Since most funds did not issue debt, they may have desired regulation to prohibit other funds from issuing debt in order to maintain a single public image for the entire industry. Funds that issued only common stock might have feared that if other funds issued more complicated securities, then investors might easily have become overwhelmed by the array of options, and might have chosen not to invest in mutual funds at all, rather than to spend substantial time sorting through all of the options. ${ }^{50}$

A final possible explanation is simply that the SEC and the industry lacked the experience necessary to foresee the industry's future evolution. Closed-end funds did not come into existence until the mid-1920s, and openend funds did not become a meaningful force until the mid-1930s. ${ }^{51}$ Thus, by the time the ICA came along in 1940, the SEC, Congress and even the industry

46. Id. pt. 2 at $320-23$ ("Prior to the 1929 security price decline the common stocks of the leverage companies sold at premiums over asset value, apparently more sizable than those which existed for nonleverage issues.").

47. Closed-end and open-end funds were operated by separate groups of people. Closed-end funds were mostly managed and underwritten by investment banks and brokerage houses based in New York while open-end funds were mostly managed and underwritten by small wealth-management shops based in Boston. SEC. \& EXCH. COMM'N, supra note 45, pt. 2 at 214-15; Grow, supra note 40, at 26-38.

48. 15 U.S.C. $\S 80 \mathrm{a}-18(\mathrm{f})(1)(2006)$ only prohibits funds from issuing senior securities, not from maintaining existing issues.

49. Morley, supra note 36 , at $380-81,386-88$.

50. Morley, supra note 36 , at 386-88.

51. SEC. \& EXCH. COMM'N, supra note 45, pt. 1 at 56; Morley, supra note 36, at 348-51. 
may not have understood the potential for future growth through senior securities issues by open-end funds.

\section{The Incoherence of Mutual Fund Capital Structure Regulation}

One might imagine several purposes for the regulation of mutual funds' capital structure, including and in addition to the original motivations just described. The possible purposes include limiting systemic risk, limiting equity investors' risk, limiting investor confusion, and preventing closed-end funds from trading at premiums to net asset value. All of these purposes could plausibly support some type of regulation. However, they do not support regulation as it currently stands. The ICA does both too much and too little to achieve any of these various purposes.

\section{A. Systemic Risk}

The most obvious purpose might have to do with risks to the financial system. We might want to prevent mutual funds from borrowing so that they do not default on their debt and externalize costs to the financial system. A default by a mutual fund might externalize costs to the financial system by destabilizing the fund's lenders or by creating fear among investors that other funds might similarly default.

This goal of limiting risks to the financial system may make sense, but the capital structure regulations in the ICA are not actually consistent this goal. Most important, the ICA does not apply to hedge funds. Like the other securities laws, the ICA exempts funds that issue securities only to wealthy individuals and institutions, regardless of how much systemic risk these funds pose. $^{52}$ The result is that hedge funds are exempt from the ICA's capital structure regulations and can borrow in almost any fashion they choose, even though they are structurally very similar to mutual funds and even though they often make similar investments.

The logic behind exempting hedge funds from the ICA is that hedge funds' investors are sophisticated enough to protect themselves. This makes sense only if we think the purpose of regulation is to protect investors. It does not make sense if we think the purpose of regulation is to protect the financial system. The systemic risk posed by a fund depends on its size, complexity and leverage ratio, and not on whether its shareholders are wealthy or sophisticated. It is almost as though hedge funds are being allowed to pollute the financial markets with risk just because their investors are rich. This is not fair.

Some might argue that because hedge funds can offer securities only to a narrow class of investors, hedge funds are smaller and therefore less systemically significant than mutual funds. This argument does not quite work.

52. 15 U.S.C. $\$ 80 a-3(c)(1),(7)(2006)$. 
Although hedge funds hold fewer assets as an industry than mutual funds do, individual hedge funds can be quite large and quite complex. Bridgewater Associates, for example, manages about $\$ 130$ billion in assets across a handful of very large hedge funds. ${ }^{53}$

Systemic risk concerns also do not easily explain the ICA's disparate treatment of bank borrowing and debt securities. Systemic risk concerns might warrant regulation of the amount or form of borrowing, but not necessarily the sources of the borrowing. If the concern for systemic risk is about the amount of mutual funds' borrowing, then it makes little sense to differentiate between borrowing that comes from banks and borrowing that comes from the public, so long as the borrowing occurs in similar amounts. Alternatively, if the concern is about the form or complexity of borrowing, then the ICA should not prohibit plain vanilla short-term bonds. Further, the ICA should regulate the complexity of bank borrowings and derivative transactions as well as the complexity of public debt issues. Currently mutual funds are free to enter indefinitely complex borrowing arrangements with unlimited numbers of banks and derivative counterparties.

\section{B. Investor Risk}

Another possible rationale involves concern for equity investors. One might worry that leverage increases the riskiness of returns to equity investors, and equity investors might not understand or appreciate this risk. This concern is particularly important because mutual funds often attract unsophisticated household investors.

Leverage increases risks to equity holders by magnifying gains and losses. Imagine, for example, a fund that has $\$ 100$ in equity and $\$ 100$ in debt, for a total of $\$ 200$ in assets. Because some of the fund's assets come from debt, its total assets are greater than its equity, and so returns on the total assets are magnified for equity holders. If the fund experiences a $10 \%$ return on its total assets-i.e., $\$ 20$-this will translate into approximately a $20 \%$ return on its equity. ${ }^{54} \mathrm{~A} 10 \%$ loss would be similarly magnified.

Even if one accepts that protecting equity investors from these risks is a good goal, however, it is clear that the current regulations are not well designed to achieve it. If the goal is to protect equity holders from the risks of leverage, then the distinction between leverage that comes from bank borrowing and leverage that comes from senior securities is arbitrary. The risks to a fund's equity holders are substantially the same regardless of whether the fund's

53. Michael Corkery \& Steve Eder, Bridgewater Goes Large, WaLl ST. J., June 22, 2011, http:/online.wsj.com/article/SB10001424052702304887904576399983107988642.html; Our Company, BRIDGEWATER ASSOCS., http://www.bwater.com/home/our-company/company.aspx (last visited Jan. $25,2013)$.

54. I say "approximately" because the fund would have to pay its creditors an interest rate that would diminish the actual return on equity to less than $20 \%$. 
borrowing comes from banks or bondholders, so long as the terms of the borrowing are similar.

Additionally, mutual funds are capable under current regulation of generating unlimited risk for their equity holders without using any borrowing at all, because the ICA does not regulate the riskiness of portfolios. Mutual funds may therefore generate arbitrary levels of risk without using leverage simply by allocating their portfolios appropriately. For example, the ICA allows a mutual fund to invest its entire portfolio in call options that are so far out of the money that the odds of their paying off are vanishingly small. Stock in such a fund would be extraordinarily risky-its payoff structure would resemble a lottery ticket-but this strategy would not involve any borrowing and would be perfectly legal under the ICA. ${ }^{55}$

In its disregard of portfolio risk, the ICA stands in contrast to bank regulation. Like mutual fund regulation, bank regulation restricts the amount of debt banks can carry. Unlike mutual fund regulation, however, bank regulation also restricts the riskiness of banks' portfolios by regulating, at least to some extent, the riskiness of banks' loans and other assets. ${ }^{56}$ Bank regulation, in other words, is a comprehensive system of risk regulation: it regulates both capital structure and assets. The ICA, however, is only a partial system of regulation: it regulates only capital structure.

\section{Investor Confusion}

Another possible rationale for the capital structure regulations is that investors might become confused if the array of options for investing in mutual funds became too large or too varied. This is a version of the "collective branding" idea that I have proposed elsewhere as a possible explanation for the open-end fund industry's original acceptance of the senior securities prohibition in $1940 .{ }^{57}$ One might worry that if the array of securities offered by mutual funds becomes too complicated, then unsophisticated household investors might be overwhelmed by the time and effort required to sort through them. The cost of trying to understand whether a possible investment is actually debt or actually equity might be so high to unsophisticated investors that they might simply abandon the effort to invest in mutual funds altogether or might prefer instead to be offered only equity securities.

This rationale is different from the concern discussed above about protecting equity investors from risk. Here the concern is not that allowing mutual funds to issue debt will make the equity excessively risky. Rather, the

55. Perhaps investors might bring some generic fiduciary duty challenge, but there is no specific provision in the ICA that prohibits risk-taking per se.

56. RICHARD SCOTT CARNELL ET AL., THE LAW OF BANKING AND FINANCIAL INSTITUTIONS, 296-307 (4th ed. 2009).

57. Morley, supra note 36 , at $459-61$. 
concern is that allowing mutual funds to issue debt will present investors with too many complex options, so that investors will have to spend too much time and effort making choices.

There is some reason to be skeptical of this concern. Many mutual fund investors are so lacking in basic financial knowledge that a subtle change in capital structure or in the nature of securities being offered might not even register to them. ${ }^{58}$

This rationale makes a certain amount of sense, but the regulation is almost certainly more restrictive than this rationale warrants. Ensuring the simplicity of investors' options probably does not require the draconian prohibition of all kinds of senior securities that appears in the ICA. We could probably ensure adequate simplicity just by standardizing the kinds of debt that funds can issue and by requiring the standard forms to be simple and easily understandable. In other words, it might be enough to say that mutual funds can issue debt but only in the form of plain-vanilla coupon bonds with a limited variety of terms.

Additionally, regulation already permits substantial complexity. Mutual funds can already make the risk and return profiles of their equity securities arbitrarily complicated and opaque by using obscure investment strategies or by borrowing money from banks and entering into derivative transactions. In other words, adding on senior securities might make mutual fund capital structures somewhat complicated, but funds can already achieve extreme complication through the use of derivatives. For example, the SEC has already created a special class of mutual funds-money market funds-that offer securities on substantially different terms from ordinary mutual funds.

The complexity already present in mutual funds is important because it suggests once again that mutual fund capital structure regulation is incoherent. It is not well designed to achieve the goals we might imagine for it.

\section{Preventing Closed-End Funds from Trading at Premiums to NAV}

A final rationale reaches back to the origins of the ICA: Perhaps the goal of capital structure regulation is to prevent closed-end funds from trading at premiums to net asset value. Recall that prior to the Great Crash of 1929, many closed-end funds' stocks traded at prices above the funds' net asset values, and this tendency was most pronounced in funds with substantial debt capital.

Regulation is not fully consistent with this rationale, either. Most obviously, this rationale does not explain why we need to regulate the capital structures of open-end funds. For mechanical reasons having to do with

58. See, e.g., James J. Choi et al., Why Does the Law of One Price Fail? An Experiment on Index Mutual Funds, 23 REV. FIN. STUD. 1405 (2010) (documenting investors' failure to minimize fees in an experimental setting even when the investors have been offered a choice among a fixed array of S\&P 500 index funds). 
redemption rights, open-end funds' share prices cannot deviate substantially from NAV. ${ }^{59}$

Additionally, it seems highly unlikely that closed-end funds will actually trade at premiums to NAV at any time in the future, no matter how much debt they are permitted to assume. No closed-end fund has consistently traded at a premium to NAV since the Great Crash of 1929, and almost all closed-end funds now consistently trade at discounts to NAV. ${ }^{60}$ It is unlikely that discounts are a product of the current restrictions on capital structure, because closed-end funds began trading at discounts in 1929-11 years before they became subject to regulation in 1940. Further, closed-end funds are already able to issue significant amounts of debt under the ICA, meaning that if debt really did make closed-end funds trade at premiums to NAV, they would probably be trading at premiums now.

The period before 1929 when closed-end premiums were linked to debt was probably just a historical aberration. Back then closed-end funds were a very new invention-the first closed-end funds started operating in the mid1920 s - and people did not quite know what to make of them. ${ }^{61}$ Closed-end funds were unbelievably popular in the late $1920 \mathrm{~s}$, however. Their securities accounted for approximately one-third of all new issues in $1929,{ }^{62}$ which witnessed perhaps the greatest market for new securities issues in history. The public has never had such enthusiasm for closed-end funds in the years since, and it is unlikely the public will ever have such enthusiasm again in the future.

\section{The Uneasy Case for Prohibiting Debt Securities}

The incoherence of mutual fund capital structure regulation is perhaps most acute with respect to the restriction on debt issuance to the public. There is no compelling reason why mutual funds should not be allowed to issue debt securities to the public.

\section{A. A Proposal}

To illustrate how mutual funds might issue debt securities, I will start with a simple but concrete proposal for what these securities might look like. To be clear, I am not arguing that this proposal offers the single "best" way of

59. John Morley \& Quinn Curtis, Taking Exit Rights Seriously: Why Governance and Fee Litigation Don't Work in Mutual Funds, 120 YALE L.J. 84, 104-05 (2010). The basic idea is that a fund cannot sell for less than NAV or redeem for more than NAV, because then the fund would become a Ponzi scheme. Imagine, for example, a fund with $\$ 100$ in assets and 100 shares outstanding. Dividing $\$ 100$ by 100 shares, we can calculate the NAV as $\$ 1$. If the fund redeemed at a price above its NAV, say $\$ 2$, the fund would run out of money after redeeming only 50 of its 100 shares.

60. See generally Elroy Dimson \& Carolina Minio-Kozerski, Closed-End Funds: A Survey, FIN. MARKETS, INSTITUTIONS \& INSTRUMENTS, May 1999, at 1.

61. Morley, supra note 36, at 348-54.

62. SEC. \& EXCH. COMM'N, supra note 45, at 186 tbl.59. 
structuring mutual funds' debt securities. Rather, the proposal is designed to provide a concrete illustration of the mechanics of how debt issuance might work. This proposal is deliberately conservative in the sense that it calls for relatively strong regulatory restrictions that could reduce the risk of financial distress among issuing mutual funds and the risk of confusion among investors. I am making this proposal relatively conservative in order to abstract away from concerns about financial distress and other problems that might distract readers' attention from the main points, which are that (1) debt securities are practically feasible and (2) we can choose whatever level of risk we would like these securities to pose by simply setting regulatory limits appropriately. Accordingly, after describing the basic proposal in Subsection IV.A.1, I explore some of the possible and more permissive variations in Subsection IV.A.2.

\section{Basic Proposal}

Debt securities might be limited in both amount and form. The amount restrictions might be designed to ensure that debt securities pose roughly the same risk of default as bank borrowings. In other words, mutual funds could be required to maintain the total asset coverage ratio of $3 / 1$ that currently applies to bank borrowings. For purposes of calculating this ratio, debt securities and bank borrowings might be combined and treated cumulatively as borrowing. Mutual funds might be required to maintain their debt-equity ratios continuously, just as they are now required to do for bank borrowings. In other words, if their equity decreases, they might be required to prepay and reduce their debt within three days to maintain the appropriate asset coverage ratio. ${ }^{63}$

The form restrictions might be designed to ensure that the debt is easy to understand and easy to value, so as to minimize the complexity and confusion created by the new securities. Form could be regulated on several dimensions. First, mutual funds could be allowed to issue debt in only a single layer of priority. The assets could be deposited with a trustee or made subject to a security interest of the debt holders to ensure that other lenders, such as banks, would not gain priority over public debt holders. The assets subject to the trust or security interest could consist of liquid securities, such as cash and exchange-traded stocks and bonds, in amounts equal to some multiple of the outstanding principal, such as 1.2 or 1.3. If the assets were deposited in trust, the trustees might either be new trustees appointed specifically for the purpose of serving as indenture trustees, or they might be the same custodial trustees who are already required by law to hold mutual funds' assets. ${ }^{64}$ Funds could be allowed to freely remove and replace assets from the pools held for the interests

63. If debt holders were forced to redeem early, their money could be delivered using the same mechanical procedures that ordinary companies and closed-end funds now use to pay dividends. Forced redemptions could be done pro rata by reducing each investor's principal amount in proportion to his or her holdings. Redemptions would have to occur at face value.

64. 15 U.S.C. $\S 80 \mathrm{a}-17$ (f) (2006); 17 C.F.R. $§ 270-17 \mathrm{f}-2$ (2012). 
of debt holders, so long as the funds replaced the assets with other assets of equivalent value. The assets in the pools should be off-limits for paying redemptions and operating expenses and for securing bank loans or derivative trades, however. If ever a fund's debt-equity ratio fell so low that the required ratios were breached, the fund should have to cease operations immediately and liquidate. This should theoretically leave enough for everyone to be paid in full.

Second, both debt and equity should be redeemable with a frequency that is standardized across the industry. The redemptions might occur daily, although it is possible to imagine less frequent redemptions. Maturities may or may not be subject to regulation, depending on how deeply we are concerned about the possibility of default on debt.

Third, the debt should be required to be plain vanilla. Regulation should prohibit convertibility or other exotic features to ensure that investors are not confused and overwhelmed by the array of available options.

Fourth, interest should accrue with the same frequency that equity and debt redemptions are processed. If equity redemptions are processed daily (as they currently are in most mutual funds), then interest should accrue daily. Such an accrual system is necessary to ensure that equity investors who redeem before interest is paid are charged with their proportionate shares of interest payments.

Fifth, interest rates should not be subject to regulation. ${ }^{65}$ Funds should be allowed to set their own maturities and interest rates, and they should be allowed to issue different classes of debt with different maturities and interest rates, so long as the different classes do not differ in terms of priority.

Sixth, fund advisers should be allowed to charge fees to debt holders. We might imagine several different mechanisms for charging the fees. One would be for advisers to take a portion of the interest the funds pay to debt holders. For example, if a fund offered debt with a $3 \%$ annual interest rate, the advisers could take a portion of the interest-say $10 \%$ of it--and leave the debt holders with the rest (in this case a net rate of $2.7 \%$ ). The withheld $0.3 \%$ would go to the adviser, rather than to the fund. Another technique would simply be for advisers to charge the equivalent of underwriting or load fees at the time new debt securities were issued. That is, when a fund issues a new bond, the advisers could be entitled to a portion of the purchase price, with the remaining proceeds going to the fund.

This proposal could be implemented either through administrative rule reforms by the SEC or through statutory changes by Congress. Administrative rule reforms might work because the ICA gives the SEC extremely broad

65. Of course, the requirement that mutual funds maintain the required debt-equity ratio on an ongoing basis must mean that long- and medium-term debt would have to be subject to prepayment if a fund's debt-equity ratio ran a foul of my proposed limit. 
discretion to create exemptions to the statute. ${ }^{66}$ The political support for such a reform would most likely come from the mutual fund industry itself. The industry might support allowing debt securities because it might expect to charge fees to debt investors.

I do not propose any changes to closed-end funds. Closed-end funds can already issue bonds and preferred stock. Moreover, closed-end funds nowadays comprise a small and insignificant industry, and they are unlikely to grow into a large industry because of their puzzling tendency to trade at discounts to net asset value.

\section{Possible Variations}

This is the basic proposal, but one could imagine many possible variations. Let us briefly consider a few of the most interesting.

One variation would allow the price of the equity to float in a way that reflected its riskiness. For reasons explained above, redemption rights in mutual funds force the price of mutual funds' equity always to equal NAV. ${ }^{67}$ The problem this creates is that NAV is a measure of liquidation value, not expected value. This means that the price of the equity does not necessarily increase or decrease to reflect overall portfolio risk.

We might address this possibility by treating the equity as a kind of junior debt interest. The equity shares could be given junior priority behind the debt, but could also be given some fixed payoff at a future date in the near term-say $\$ 1$ per share one week from the date of issuance. The funds could then auction a portion of the equity every day at a price that cleared the market. Such a price would reflect both prevailing interest rates and the market's expectations about the riskiness of the equity.

Another variation would be to take a more direct route to risk regulation and make debt ratios into a direct function of portfolio riskiness for all funds. Professors Andrew Lo and Thomas Brennan have recently proposed that for banks, debt restrictions should be set as a function of portfolio volatility so that the probability of loss of a specified percentage of the portfolio remains fixed. ${ }^{68}$ In other words, as volatility goes up, leverage would have to go down to maintain a fixed probability of a certain amount of loss. We might apply such a system to mutual funds that issue debt securities in order to maintain a fixed probability of default.

A related variation might tie debt limits to liquidity: funds with more liquid portfolios could issue more debt securities. Such a scheme might limit

66. 15 U.S.C. $\$ 80 \mathrm{a}-6$ (c) (2006) ("The Commission ... may conditionally or unconditionally exempt ... from any provision or provisions of this subchapter ....").

67. See supra note 59 for an explanation.

68. Andrew W. Lo \& Thomas J. Brennan, Do Labyrinthine Legal Limits on Leverage Lessen the Likelihood of Losses? An Analytical Framework, 90 TEX. L. REV. 1775 (2012). 
the risk of liquidity crises when funds experience sudden and massive equity or debt redemptions. To be clear, mutual funds already face substantial liquidity regulation. The SEC has prohibited ordinary mutual funds from investing more than $15 \%$ of their assets in illiquid investments. ${ }^{69}$

A final variation would require equity and debt to be purchased together in units. In this variation, anyone who buys a debt security would also be required to buy an equity security. The units might be tied together so that they could not be traded separately. Jeff Gordon has proposed something like this for institutional investors in money market funds. ${ }^{70}$

The advantage of forcing equity and debt to be sold as units is that it would reduce the risk that debt holders would be left without insulation as a result of sudden and massive redemptions of equity, since no one who held debt could redeem their equity without also redeeming their debt. The disadvantage of tying equity and debt together is that it would eliminate many of the efficiencies that come from dividing risks between equity and debt holders. Additionally, forcing debt and equity to be sold as units just seems unnecessary. Prior experience with bank borrowing and pre-1940 debt issues has already proven that open-end mutual funds can issue debt and equity without tying them together. Further, requiring equity and debt to be sold in units would not completely eliminate the possibility of default, since equity might disappear through portfolio depreciation as well as through redemption.

\section{B. Benefits}

The benefits of allowing mutual funds to issue debt securities would likely accrue primarily to the prospective buyers of this debt. These benefits are what might assure the strength of demand for mutual fund debt securities. Demand for shares in money market funds remains quite strong in spite of the events of the financial crisis, and because debt securities offer several advantages relative to money market funds, it seems reasonably likely that the market for debt securities would be strong as well.

The advantages of debt relative to money market funds and equity interests in other types of mutual funds are several. First, debt securities could offer fixed interest rates. Fixed interest rates are currently not available in any type of mutual fund-not even in money market funds. Under current regulation, the value of common stock in most mutual funds floats with the net asset value, and equity investors only receive dividends equal to the fund's

69. Revisions of Guidelines to Form N-1A, 57 Fed. Reg. 9828 (Mar. 20, 1992); see also Audrey C. Talley et al., Restrictions on Investments, in MUTUAL FUNDS AND EXCHANGE-TRADED FUNDS REGULATION $\S 8: 3$ (Clifford E. Kirsch ed., 3d ed. 2012). The SEC defines an asset as being "illiquid" if the fund cannot sell it within seven days at approximately the value at which the fund carries the asset on its books. Acquisition and Valuation of Certain Portfolio Instruments by Registered Investment Companies, 51 Fed. Reg. 9773, 9777 (Mar. 12, 1986).

70. Gordon, supra note 4 , at 3. 
profits-whatever those profits may be. Money market funds offer common stock with fixed net asset values, but even money market funds cannot promise any particular rate of dividends on this stock. The only way an investor in any type of mutual fund can predict his or her returns is to look at the fund's fees and prior returns and make an educated guess about what the future returns are likely to be. By contrast, an investor who buys a bond from a mutual fund that pays $3 \%$ could know with near certainty that she would receive exactly $3 \%$ over the life of the bond, subject only to the possibility of default (which in most instances would likely be quite low).

Knowing returns in advance might be quite useful for any number of reasons. For example, it might make comparison-shopping easier. If Fund $\mathrm{A}$ offers 3\% and Fund B offers $3.1 \%$, an investor's choice is much simpler than if Fund $\mathrm{A}$ and Fund $\mathrm{B}$ both offer common stock with uncertain returns. Fixed interest rates also allow superior planning. Investors who know precisely how much interest they will earn from their mutual fund bonds can more easily use the interest payments to hedge or otherwise plan for the future.

A second benefit, in addition to fixed interest, is that debt securities might offer investors an actual senior claim. At present, no mutual fund can offer a fixed principal claim that is insulated from losses by equity, because no mutual fund can issue securities in more than one layer of priority. Even money market funds, which nominally have fixed-value shares, cannot offer investors protection from losses by more junior claimants. If a money market fund's net asset value falls below $\$ 1$, the fixed-net asset value stockholders are the first in line to bear losses. Debt securities might thus offer a less risky investment than equity. Even the equity of funds that invest in corporate and government debt would be more risky than debt securities, because the equity of debt funds does not offer fixed interest rates or senior priorities.

As noted above, many institutional and retail investors already prize the fixed net asset values offered by money market fund shares for a variety of reasons. These reasons include legal requirements that institutional investors buy only fixed-value investments, a desire to avoid the capital gains tax accounting that might come from floating value investments, and a desire (among retail investors) to treat their investments like demand deposits. ${ }^{71}$

Debt securities can offer all of these advantages to an even greater degree than money market funds. The nominally fixed-NAV shares of money market funds cannot guarantee the same level of safety that debt securities could, because money market funds cannot offer insulation from losses by more junior claimants. $^{72}$

71. See Fisch \& Roiter, supra note 32, at 1015-16.

72. To be clear, it is possible to imagine debt securities that might be riskier than money market fund common stock. Debt securities might become risky if the equity cushion is small or if the fund's assets are highly volatile. The argument here is simply that the maximum degree of safety that could be offered by debt securities is higher than the maximum degree of safety that could be offered by money market fund common stock. 
Investors might also prize the fixed interest rates and senior priorities associated with debt securities because they might increase the securities' usefulness as collateral. Equity is less useful as collateral than debt, because equity cannot be rated by a rating agency since it does not have a senior priority or fixed interest.

\section{Arguments Against Allowing Debt Securities}

So far, we have considered reasons why mutual funds should be allowed to issue debt. We might flip the argument around, however, and consider reasons why these funds should not be allowed to issue debt. This way of viewing the problem is useful, because in the United States we generally allow companies to determine their own capital structures unless there are compelling reasons to the contrary.

\section{The Risk of Default}

Several of the objections to allowing mutual funds to issue debt securities are founded on the concern that mutual funds might default on their debt. Concerns about systemic risk, risk to investors and the potential for government bailouts are all founded on the worry that funds might default. Let us therefore begin the treatment of objections by addressing the possibility of default directly.

The most important observation is this: if default is a concern, then regulation should simply address the risk of default. The prohibition against debt securities does not do this. Instead of regulating the risk of default, it regulates only the source of credit. This makes little sense, because the risk of default is primarily a function of the amount and form of credit, not the source.

One might worry that amount and form restrictions may be insufficient. After all, banks face regulation of the amount and form of their debt, yet many banks collapsed during the recent financial crisis. Mutual funds could be made much safer than banks, however. Indeed, the probability of default in mutual funds could easily be reduced to nearly zero, for two reasons: (1) capital ratios in mutual funds could be set with much greater conservatism than capital ratios in banks; and (2) mutual funds have much greater liquidity than banks, and they already handle tremendous liquidity pressures with aplomb.

First, recall from the discussion above that mutual funds' capital ratios are already much more conservative than those of banks. Banks routinely receive more than $90 \%$ of their capital from debt, but under current law mutual funds may receive only up to $1 / 3$ of their total capital from debt. ${ }^{73}$ We could easily maintain similar or only slightly more permissive ratio requirements in mutual funds for debt that comes from senior securities.

73. 15 U.S.C. $\$ 80 \mathrm{a}-18(2006)$. 
We could also require mutual funds to maintain their capital ratios continuously, just as they are now required to do if they borrow from banks. ${ }^{74}$ Mutual funds might maintain their capital ratios continuously by issuing debt securities that have very short maturities. If the debt matures within a day or two, for example, a fund that is experiencing large declines in equity could restore balance simply by choosing not to reissue its debt. Alternatively, mutual funds might maintain their capital ratios by building terms into their debt securities (either through regulation or contract) that allow the funds to prepay their debt securities if the funds violate their required capital ratios. Prepayments could be made pro rata, so that all debt holders of the same maturity might receive prepayments proportional to their holdings. The mechanics of prepayments would probably be no more complicated than the mechanics of paying dividends to stockholders. Prepayments have the potential to upset debt holders' expectations, but this might be a problem debt holders would be willing to live with.

Of course, requiring mutual funds continuously to maintain conservative capital ratios would require mutual funds to maintain great liquidity. If a fund were suddenly forced by capital requirements to prepay or not renew its debt, then the fund would have to be able to quickly sell off the portion of its portfolio that corresponded to debt. That is, if a fund suddenly had to pay off $\$ 1$ million in debt, it would have to sell off $\$ 1$ million of investments.

This would likely not be a problem, because mutual funds have already been structured to survive tremendous liquidity pressures. Unlike ordinary companies and banks, mutual funds are required by regulation to be prepared to redeem all of their equity holders-and thus to give up all of their capitalevery day. ${ }^{75}$ Open-end funds deal with this problem by investing primarily in highly liquid exchange-traded securities. By regulation, they can invest no more than $15 \%$ of their capital in assets that cannot be sold at or near book value within seven days. ${ }^{76}$ Ordinary mutual funds have thus dealt with the tremendous liquidity pressures created by redemptions almost without problems over the years.

\section{Systemic Risk}

There are at least two reasons to worry about systemic risk. First, if a mutual fund defaults on its debt, it might send ripples through the financial system and externalize harm to third parties unconnected to the fund. The responses to this concern track the arguments about default risk above: the risk that mutual funds will default could be made extremely low, and in any event,

74. Id.

75. The ICA technically only requires redemption every seven days, but as a practical matter, almost all funds pledge to redeem every day. 15 U.S.C. $\$ 80 \mathrm{a}-22(\mathrm{e})(2006)$.

76. See supra note 69. 
if we are worried about systemic risk, then we should regulate systemic risk directly. The prohibition on senior securities does not do this, since it leaves mutual funds free to engage in other systemically risky transactions, such as bank borrowing and derivatives. Regulators can address systemic risk directly by regulating default risk, as discussed above, and by regulating complexity. They could regulate complexity by, for example, allowing funds to issue only plain vanilla bonds with no complicated terms, as my proposal above would do.

Note also that prohibiting mutual funds from issuing senior securities may actually be aggravating the effect of a mutual fund default on systemic risk, rather than reducing it. By prohibiting mutual funds from issuing senior securities, the ICA forces them to obtain leverage instead from banks and derivative counterparties. The ICA thus channels leverage into financial institutions that may be too big or too complex to fail, rather than distributing it across many small investors.

A second reason to worry about systemic risk is that if mutual funds have to maintain a constant capital ratio, then they might aggravate macroeconomic cycles as they lever up and down in response to these cycles. ${ }^{77}$ In particular, during periods of massive stock market declines, mutual funds might be forced to sell off portions of their portfolios to raise the cash necessary to retire debt and maintain minimum asset coverage ratios. Given the mutual fund industry's enormous size, massive sell-offs by leveraged funds during periods of market declines could potentially force securities prices further downward, creating a feedback loop in which further declines promote further sell-offs, and so on.

This is a very serious concern. Perhaps the best counter-argument is that this concern is not unique to mutual funds, or to leverage created by the issuance of senior securities. Any time a borrower commits to continuously maintain a capital ratio, there is a risk that the borrower will be forced to sell off assets during periods of market decline. This is just as true of banks and hedge funds as it is of mutual funds, and it is just as true of leverage that comes from banks and derivative counterparties as it would be of leverage that comes from debt securities.

\section{The Mechanical Challenges of Redemption Rights}

Another set of concerns has to do with mechanical problems arguably created by equity redemption. One such concern is that equity redemptions might cause a fund's capital to disappear suddenly. If many of a fund's equity holders suddenly redeemed, then the debt holders might be left with little insulation to cushion them from declines in the value of the fund's portfolio.

This prospect need not trouble us, however, for the reasons already described. When equity holders redeem, they take only the equity - that is, they

77. See generally John Geanakoplos, The Leverage Cycle (Cowles Foundation for Research in Econ. at Yale Univ., Discussion Paper No. 1715, 2009), available at http://ssrn.com/abstract=1441943. 
take the assets that are left over once the debt has been accounted for. Thus, at least in theory there should be enough money left to pay the principal on the debt even if all of a fund's equity suddenly redeems. Additionally, mutual funds have highly liquid portfolios, and so as long as their debt has short maturities or so long as they can prepay their debt, they can maintain a constant equity coverage ratio. If a dollar of equity redeems, then a fund can maintain an asset coverage ratio of $3 / 1$ simply by prepaying or declining to roll over fifty cents of debt.

One might argue that equity redemptions are troubling because they could snowball through a "run." In bank runs, fears about liquidity become selffulfilling prophecies. Depositors try to withdraw not because they need the cash, but because they fear that other depositors who withdraw first will take all of the bank's liquid assets and leave the depositors who withdraw later with nothing.

Mutual fund equity holders have little reason to run, however, because unlike the claims of bank depositors, mutual fund equity holders' claims are residual, not fixed. When mutual fund equity holders redeem, therefore, they receive only their proportional shares of a fund's net assets, rather than a fixed amount of money. This avoids the central problem of bank runs, in which people try to get out early because there are too few assets to satisfy every depositor's fixed claims. Mutual fund equity holders' claims automatically adjust upward and downward with the amount of money available in the fund.

Of course, debt holders in mutual funds might have some reason to run by redeeming or refusing to roll over their debt, but I have addressed this problem above: the prospect of runs by debt holders is not worrisome because mutual funds maintain sufficient liquidity to meet large demands on their capital, and because debt holders are unlikely to perceive a serious risk of default.

Another concern related to equity redemption is that debt might complicate the process of valuing a fund's portfolio and processing equity redemptions. Portfolio valuation is a matter of central importance in funds that offer redemption rights, because when an equity holder redeems, she must be paid an amount exactly equal to the net asset value. The net asset value is, in essence, the value per share of the fund's assets minus its liabilities. If a shareholder receives more than the net asset value, she will receive more than her proportional share and will take assets from other equity holders. If she receives less than the net asset value, she will receive less than her proportional share and the other equity holders will gain an unfair windfall. Since the net asset value is a function of both assets and liabilities, one might worry that the existence of too many liabilities on a fund's balance sheet might complicate the valuation of the portfolio.

The simplest answer to this concern is that mutual funds have apparently already developed mechanisms to address it, because they already have debtthey just obtain this debt from banks and derivative counterparties, rather than from the general public. Mutual funds have other liabilities as well, such as the 
fees they pay to underwriters and managers. Hedge funds also have debt, even though they offer equity holders redemption rights. Whatever challenges debt creates for portfolio valuation in open-end funds are therefore already upon us. The exact accounting methods that funds have developed for dealing with balance sheet liabilities are complicated, but they clearly exist and are clearly capable of doing the job.

Another concern about equity redemption is that it limits funds' ability to maintain their capital ratios by selling new equity at a discount. When banks are at risk of violating their capital ratios, they often solve the problem by issuing new equity at below-market prices. Issuing equity at low prices allows them to find buyers relatively easily. Mutual funds cannot do this, because to sell their equity at a discount would create an arbitrage opportunity. If, for example, a fund's net asset value were $\$ 10$, and the fund sold new shares for $\$ 9$, then the new investors could make a $\$ 1$ profit by just buying and then redeeming immediately. The $\$ 1$ would come out of the pockets of the equity holders who remained. The solution to this problem is to look at the other side of the capital ratio: instead of increasing their equity, funds can reduce their debt. This is the logic behind the suggestion above that mutual fund debt securities should either have short maturities or be prepayable. ${ }^{78}$

\section{The Modigliani-Miller Theorem}

A closely related concern derives from the Modigliani-Miller Theorem. ${ }^{79}$ The Modigliani-Miller Theorem states that where several strong assumptions hold, an enterprise's capital structure is irrelevant to the enterprise's value. The enterprise will ultimately be worth the same regardless of the relative portions of debt and equity in its capital structure. The idea, basically, is that if investors want more leverage, then they can buy equity from an unleveraged company and obtain leverage on their own by opening a margin account or taking out a home equity loan. The theory thus seems to imply that there would be no benefit to allowing mutual funds to issue senior securities, since prospective equity holders could simply leverage on their own, rather than having the funds do it for them.

Mutual funds might nevertheless gain from issuing debt for two reasons. First, the Modigliani-Miller hypothesis assumes that equity holders and companies can borrow at equal rates. ${ }^{80}$ This assumption likely does not hold in

78. See supra Subsection IV.C.1.

79. Franco Modigliani \& Merton H. Miller, The Cost of Capital, Corporation Finance and the Theory of Investment, 48 AM. ECON. REV. 261 (1958).

80. Commentators differ on precisely which assumptions are essential to the ModiglianiMiller theory, but Professor Joseph Stiglitz offers a reasonable summary. See Joseph E. Stiglitz, $A$ ReExamination of the Modigliani-Miller Theorem, 59 AM. ECON. REV. 784, 784-88 (1969) (identifying the equal borrowing rate as an assumption but arguing that it is not necessary in some settings). Note that one of the assumptions is that debt and equity are treated equally for tax purposes. In this setting, the 
the case of mutual funds. Mutual funds can likely obtain credit on much cheaper terms than individual equity investors can. Funds are larger, more transparent and more accountable to creditors than individual investors are. And funds can likely handle the administrative headaches associated with issuing debt much more easily than individuals can. Setting up a margin account or taking out a home equity loan is much more costly in terms of time and effort for novice investors than simply buying stock in a leveraged mutual fund. Indeed, administrative convenience is a lot of what makes mutual funds popular in the first place. If equity investors really had the resources to leverage on their own, then they would also probably have the resources to buy securities directly, rather than investing in pooled vehicles like mutual funds.

Second, debt securities might generate value for debt investors as well as for equity investors. As noted above, debt investors might benefit from being able to buy instruments that more closely fit their tastes than existing offerings. This may be a source of value, even if it does not increase funds' cash flows.

\section{The Demand for Equity Interests}

Perhaps the most difficult question is whether anyone would buy the equity in funds that issue debt securities. One might doubt investors' willingness to buy equity for two reasons: (1) equity investors might not want to invest in leveraged funds at all; and (2) even if they do want to invest in leveraged funds, they might prefer for their funds to gain leverage through other means, such as margin accounts, short sales, or derivatives (like options and swaps). Both of these concerns gain credibility from the fact that at present mutual funds tend not to borrow from banks very frequently. Although many funds borrow from banks in small amounts to meet short-term liquidity needs, few funds borrow from banks in large amounts for the purpose of medium- and long-term investment leverage. In my view, the uncertainty about whether investors would buy equity in funds that issue debt securities is the most serious reason to doubt the potential success of mutual fund debt securities.

This concern is probably not enough to warrant maintaining the debt security prohibition, however. One reason is that we do not generally prohibit products just because we cannot say whether people will buy them. Few people outside of Apple thought the iPad would sell, but fortunately no one said it should therefore have been illegal. If indeed people fail to buy equity in funds that issue debt, then the worst that can happen is we end up with the status quo.

To put this point a little differently, we generally allow companies in the United States to determine their own forms, even though we cannot always predict when or why they will choose particular capital structures. The burden of proof when it comes to assessing the ICA and its capital structure regulations

assumption may very well hold, because mutual funds, unlike operating companies, are allowed to avoid fund-level taxes by distributing and deducting their income every year. 26 U.S.C. $\$ 852$ (2006). 
therefore properly belongs with the people defending this regulation, not the people opposing it.

Additionally, equity investors clearly do desire leverage, at least to some extent. There are a number of "leveraged" ETFs and mutual funds that use a combination of swaps and short sales to achieve leverage-like risks.

Perhaps senior securities might occasionally displace other forms of leverage because they offer lower costs and interest rates. If debt investors really do experience substantial surpluses from holding instruments that fit their tastes more closely than existing mutual fund offerings, then debt investors might be willing to pay for the privilege by accepting lower interest rates than banks.

Finally, senior securities might occasionally be more popular than other forms of leverage because senior securities might more directly benefit managers. At present, managers have relatively little motivation to use borrowing rather than other mechanisms for the achievement of risk and leverage, because managers typically cannot charge fees to equity holders based on borrowed money and they cannot charge fees to lenders. Senior securities, however, offer the prospect that managers might charge fees to the debt investors. Managers might thus be tempted to structure funds with senior securities, and they might try to attract equity holders to these funds by offering them lower management fees than in funds without senior securities, since managers might expect to make up the difference with fees charged to senior security investors.

\section{Protecting Equity Investors from Risk}

Another question is whether allowing mutual funds to issue debt securities might expose unsophisticated equity investors to risks that they cannot properly understand. As explained above, leverage magnifies the effects of gains and losses in a portfolio, and so funds that have leverage are riskier than funds with similar portfolios that do not have leverage.

Prohibiting debt securities will not actually protect equity investors from risk, however. The ICA already permits leverage from sources other than debt securities, and in any event funds can achieve arbitrary levels of risk for their equity holders simply by making risky investments.

Moreover, it is not at all clear that protecting equity investors from risk is desirable. Ian Ayres and Barry Nalebuff have recently argued-quite convincingly - that the main problem for most household investors is that they take too little risk, not too much. ${ }^{81}$ Most Americans accumulate substantial retirement savings only during the final years of their working careers. Their portfolios are thus exposed to the markets for only a few years, and they lose

81. IAN AYRES \& BARRY NALEBUFF, LIFECYCLE INVESTING: A NEW, SAFE, AND AUDACIOUS WAY TO IMPROVE THE PERFORMANCE OF YOUR RETREMENT PORTFOLIO (2010). 
out on the diversification that might occur across time if they invested more of their assets earlier in life. ${ }^{82}$ The solution is for household investors to take on more leverage. An easy and relatively safe way to do this, of course, might be to invest in leveraged mutual funds.

V. Conclusion

Although we might imagine several plausible purposes for mutual fund capital structure regulation, the current structure of regulation does not clearly serve any of these purposes. Additionally, although mutual funds' current capital structures may seem inevitable, they most likely are not. Mutual funds could issue senior securities, and there may be substantial benefits from allowing them to do so. Given mutual funds' enormous size and significance, it is quite surprising that the regulation of their capital structures has received so little attention from policymakers and economists. I hope that the questions and suggestions in this Article will encourage and guide further exploration.

82. Id. 